Discussion Paper No. 09-018

Intraday Price Formation and Volatility in the European Union Emissions Trading Scheme: An Introductory Analysis

Waldemar Rotfuß

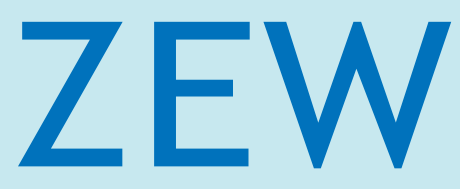

Zentrum für Europäische Wirtschaftsforschung $\mathrm{GmbH}$

Centre for European Economic Research 
Discussion Paper No. 09-018

\title{
Intraday Price Formation and Volatility in the European Union Emissions Trading Scheme: An Introductory Analysis
}

\author{
Waldemar Rotfuß
}

Download this ZEW Discussion Paper from our ftp server:

ftp://ftp.zew.de/pub/zew-docs/dp/dp09018.pdf

Die Discussion Papers dienen einer möglichst schnellen Verbreitung von neueren Forschungsarbeiten des ZEW. Die Beiträge liegen in alleiniger Verantwortung der Autoren und stellen nicht notwendigerweise die Meinung des ZEW dar.

Discussion Papers are intended to make results of ZEW research promptly available to other economists in order to encourage discussion and suggestions for revisions. The authors are solely responsible for the contents which do not necessarily represent the opinion of the ZEW. 


\section{Non-technical Summary}

This paper provides an introductory analysis of price formation and volatility in the European Union Emissions Trading Scheme (EU ETS) using high frequency data. The results show that the activity in the on-exchange market for European Union Allowances (EUAs) allocated to the first commitment period (2005 - 2007) was highest in 2006, the year in which information about possible over-allocation was released for the first time. In 2007, trading activity plunged. In contrast, trading in EUAs allocated to the second commitment period (2008 - 2012) has increased since the official start of the EU ETS in 2005. Moreover, the results show that the price discreteness in the EUA spot market (BlueNext) seems to be strongly affected by the price discreteness of the EUAs futures market (ICE Futures), supporting the strong relation between these markets; which appears to be even stronger than reported in the recent literature. However, there is still the puzzling fact that price movements of five euro cents are in both markets more frequent than price movements of three or four euro cents.

The analysis of the intraday volatility shows that activity in the EUA markets is not constant throughout the trading day. Intraday volatility rises from low levels to a high around 11:00 GMT. The typical U-shaped pattern of intraday volatility often observed in organized financial markets is partly present in the EUA futures in 2008. Similar to other classical financial markets, the realized volatility estimates of daily EUA volatility appear to have a long-memory property. The logarithmic realized standard deviation of EUA returns exhibits a more persistent dynamic dependence structure than realized volatility, realized standard deviation, or daily squared/absolute EUAs returns. The often observed normality of logarithmic realized standard deviation, however, can not be confirmed. 


\section{Das Wichtigste in Kürze}

Diese Arbeit stellt eine einführende Untersuchung sowohl der Preisbildung als auch der Volatilität im europäischen Emissionshandel (EU ETS) dar. Als Datengrundlage dienen hoch-frequente $\mathrm{CO}_{2}$-Zertifikatepreise von ICE Futures und BlueNext.

Die Ergebnisse zeigen, dass die Handelsaktivität von $\mathrm{CO}_{2}$-Zertifikaten für die erste Verpflichtungsperiode (2005 - 2007) auf den betrachteten Börsen in 2006 am höchsten ist. In dem darauf folgenden Jahr fällt die Handelsaktivität in Folge des starken Preisverfalls dramatisch ein. Der Handel von den $\mathrm{CO}_{2}$-Zertifikaten für die zweite Verpflichtungsperiode (2008 - 2012) hat sich im Gegensatz dazu seit dem offiziellen Start in 2005 positiv entwickelt. Darüber hinaus scheint die Preisbildung im Kassamarkt (BlueNext) sehr stark von der Preisbildung im Terminmarkt (ICE Futures) abzuhängen, was auf eine starke Beziehung zwischen diesen beiden Märkten hindeutet, die sogar stärker sein könnte als in der bisherigen Literatur beschrieben. Überraschend wird festgestellt: In beiden Märkten treten Preisänderungen von fünf Eurocent häufiger auf als Preisänderungen von drei oder vier Eurocent.

Im Weiteren zeigen die Ergebnisse, dass die Intratages-Volatilität der $\mathrm{CO}_{2-}$ Zertifikatepreise nicht konstant ist. Sie steigt ausgehend von einem niedrigen Niveau auf ein Tageshoch um 11:00 GMT. Der typische U-förmige Verlauf, der häufig in organisierten Märkten beobachtet wird, ist nur ansatzweise im Terminmarkt in $2008 \mathrm{zu}$ beobachten. Die realisierte Volatilität von $\mathrm{CO}_{2}$-Zertifikatepreisänderungen besitzt ähnlich zu klassischen Wertpapieren eine Long-Memory-Eigenschaft. Die logarithmierte realisierte Volatilität weist im Vergleich zur realisierten Volatilität, zur realisierten Standardabweichung, den quadrierten logarithmierten $\mathrm{CO}_{2-}$ Zertifikatepreisänderungen und dem Absolutbetrag von logarithmierten $\mathrm{CO}_{2}$ Zertifikatepreisänderungen eine stärkere Persistenz auf. Die häufig beobachtete Normalität der logarithmierten realisierten Volatilität kann jedoch nicht bestätigt werden. 


\title{
Intraday Price Formation and Volatility in the European Union Emissions Trading Scheme:
} An Introductory Analysis

\author{
Waldemar Rotfuß
}

February 2009

\begin{abstract}
This paper presents an introductory analysis of price formation and volatility in the European Union Emissions Trading Scheme using highfrequency data. The results show that there are several anomalies both in the EUA spot and EUA futures market. First, price formation seems to take place on price sets that are coarser than those offered by the exchanges. Second, price formation in the EUA spot market (BlueNext) may be strongly affected by the price formation in the EUA futures market (ICE Futures). The typical "U-shaped” pattern of intraday volatility, that is often observed in organized financial markets, is partly present in the EUA futures market. Similar to other classical financial markets, realized volatility estimates of daily EUA volatility seem to have a long-memory property.
\end{abstract}

Keywords: EUA, EU ETS, Intraday Price Formation, Realized Volatility

JEL Classification: D43; G13; Q59

\footnotetext{
* Waldemar Rotfuß, Centre for European Economic Research (ZEW), Mannheim, P.O. Box 1034 43, 68034 Mannheim, Germany, E-mail: rotfuss@zew.de; Phone: +49/621/1235/141, fax: $+49 / 621 / 1235223$. I am grateful to Jürgen Kähler, Felix Schindler, and participants at the ZEW-MAFI seminar for valuable comments and suggestions. Andreas Beck and Hela Hellerich provided able research assistance.
} 


\section{Introduction}

The European Union Emissions Trading Scheme (EU ETS), which formally entered into operation in January 2005, requires selected industrial units to participate in the trading of European Union Allowances (EUAs). Currently, the EU ETS is the largest multi-country and multi-sector emission trading scheme in the world. It includes combustion plants, oil refineries, coke ovens, iron and steel plants, as well as facilities producing cement, glass, lime, brick, ceramics, or pulp and paper. Thus, the trading scheme covers emissions from four broad sectors: production and processing of iron and steel, minerals, energy, and pulp and paper. ${ }^{1}$ The EU ETS is a cornerstone of the European Climate Change Programme to reduce greenhouse gas emissions from the combustion of fossil fuels. It aims at assisting EU Member States in meeting their commitments under the Kyoto Protocol at minimum costs, and has been called the "New Grand Policy Experiment” of market-based policies in environmental regulation. ${ }^{2}$

Ever since the official start of trading, the EU ETS has undergone some unusual price and volatility developments. Initially, it seemed that the market would operate smoothly. The price of EUAs soared towards 30 euros per tonne after remaining slightly above 20 euros for almost an entire year. ${ }^{3}$ The big surprise came in April 2006 as the Netherlands and the Czech Republic, followed by other Member States of the EU on subsequent days, reported lower than expected $\mathrm{CO}_{2}$ emissions for 2005. ${ }^{4}$ As a result, the price of EUAs crashed by almost 20 euros within few days. In the course of the following months, it became increasingly obvious that the actual emissions in the first commitment period (2005 - 2007) would be lower than the proposed cap. By the end of 2006 the price of EUAs for the first trading period amounted to about seven euros, and by the end of 2007 an average of three euro cents. While there was apparently a market breakdown in the first commitment period, trading in EUAs for the second commitment period (2008 - 2012) seems to function, despite the occurrence of certain peculiarities.

Many studies of the EU ETS focus on the design of national allocation plans (Boehringer et al., 2005), the allocation procedure of emission allowances (see Cramton and Kerr, 2002, for a general overview), the externalities on employment (Klepper and Peterson, 2004), or aspects of competitiveness (see Oberndorfer and Rennings, 2006, for a survey). However, only few empirical studies focus on the price, risk, liquidity, or the trading process of EUAs. Among these few studies are, for example, Benz and Trück (2006a, 2006b), Uhrig-Homburg and Wagner (2006a, 2006b), Borak et al. (2006), Daskalakis et al. (2006), Daskalakis and Markellos (2007), or Paolella and

\footnotetext{
${ }^{1}$ European Parliament and Council (2003).

${ }^{2}$ Kruger, J.A., Pizer, W.A. (2004).

${ }^{3}$ One European Union emission allowance gives the holder the right to emit one tonne of carbon dioxide equivalent (tCO2e) during a specified commitment phase, see European Parliament and Council (2003).

${ }^{4}$ PointCarbon (a newswire focusing on emissions markets) cited officials from the Netherlands, and the Czech Republic, who reported lower then expected emission for 2005, see PointCarbon (2006a, 2006b).
} 
Taschini (2006). These studies provide a good overview of the main properties of EUA prices, returns, and volatility. They analyze both spot and futures markets of EUAs and address selected issues of the price behavior of emission allowances in the framework of the ETS. Most of the studies propose models for the dynamic behavior of EUAs price changes and volatility, or the relationship between spot and futures markets. Moreover and with a slightly different focus, Bayer et al. (2006) address the issue of liquidity in these markets, while Mansanet-Bataller et al. (2007), Mansanet-Bataller and Pardo (2007), and Alberola et al. (2007) consider fundamental determinants of the EUA prices.

This paper extends previous findings in several important directions. We examine the market for EUAs from the perspective of financial economics. New financial markets often violate the efficient market hypothesis. Based on high frequency data, we provide an introductory analysis of the price formation and volatility in the EU ETS. We analyze both spot and futures markets and provide a range of novel aspects on empirical regularities of price changes and volatility of EUAs.

The remainder of this paper is organized as follows. We start with a brief review of the literature on the econometric analysis of EUAs prices in Section 2. Section 3 contains a description of the data used. An introductory analysis of price formation in the first and in the second commitment period is provided in Section 4. In Section 5, we analyze the volatility of EUAs. Finally, Section 6 concludes with a discussion of our main findings and suggests further research in this area.

\section{Literature Review on Studies of $\mathrm{CO}_{2}$ EUA Price Dynamics}

Benz and Trück (2006a) is one of the first empirical studies on the short-term behavior of EUA returns and volatility. Using daily broker price data on emission allowances from $08 / 2003$ - 12/2005, the authors show that EUA returns have a leptokurtic distribution and possess different states of volatility. The authors model in a follow-up analysis, Benz and Trück (2006b), price dynamics of EUAs via GARCH and Markov switching models. According to their empirical results, the volatility of EUAs returns differs dramatically in the two identified states, but regime changes do not occur very frequently. Comparing the values of the log-likelihood function and AIC/BIC of the first, the second, and the naive-model (fitting a normal distribution to the data), the authors conclude that the first (white noise processes in both states) and the second (autoregressive process in the first and white noise process in the second state) regimeswitching model clearly outperform the naive-model. An alternative modeling of EUAs returns and volatility via a $\operatorname{GARCH}(1,1)$ model results in similar information criteria. However, a forecasting evaluation of the proposed models shows mixed results. 
Another empirical study, with a slightly different focus on EUA prices, is provided by Borak et al. (2006). This study concentrates on the price behavior, the volatility term structure, and the correlations across different EUA contracts. In particular, the authors study the relationship between spot and futures markets, the changing market dynamics, and the volatility term structure of EUA spot and futures prices. The main focus lies on the analysis of convenience yields in EUA futures prices that are calculated with a costof-carry approach. The authors find high correlations (which decrease for futures with longer maturity) between EUA spot and futures prices, an upward-sloping term structure of volatility, and strong dynamics in the volatility of EUAs. Moreover, their analysis suggests significant convenience yields in futures contracts. A two-factor model of convenience yields (with contemporaneous spot prices and estimated volatility as explanatory variables) explains a large fraction of observed convenience yields in EUA futures for the second commitment period. The relationship between convenience yields and spot prices is positive in their model, while the estimated relationship with volatility is negative. The leptokurtic and heteroskedastic daily changes of convenience yields are modeled with an MA(1)-GARCH(1,1) process. However, according to this model, changes of convenience yields do not have an unconditional second central moment because the estimated parameters do not satisfy the stationary condition of the GARCH(1,1) process. This problem may be avoided when using a shorter sample period without the dramatic price drop around the end of April 2006. The authors conclude that the behavior of EUA spot and futures prices substantially differs from that of the commodities.

In contrast to Borak et al. (2006), who analyze daily EUA price data from a single exchange, Daskalakis et al. (2006) examine daily EUA prices from four European exchanges that offer spot and futures trading in emission allowances. The main aim of their study is to model the EUA price dynamics by means of stochastic processes. The analysis concentrates on the relationship between EUA spot and futures prices with maturities that fall into the second commitment period. Their findings suggest that the EUA prices are non-stationary and exhibit abrupt discontinuous shifts. Furthermore, a jump-diffusion process is found to be the most adequate process for modeling the EUA spot price dynamics. However, the authors find no significant geographical differences between daily EUA prices; daily EUA prices are very similar on all four exchanges. An analysis of the correlation between EUA returns and interest rates, major stock-market index returns, and electricity price changes shows that all correlation coefficients are negative but insignificant. Surprisingly, the authors do not find a significant correlation between EUA and electricity price changes. Considering other studies and surveys (Sijm et al. 2006; Moslener 2007; Mansanet-Bataller et al. 2007) and the fact that EUAs are a substantial cost factor for most electricity producers, it is unlikely that EUA prices are uncorrelated with electricity or energy prices, in particular with the fuel spread. 
Overall, the analysis by Daskalakis et al. (2006) suggests that the cost-of-carry approach provides an adequate model for futures prices of emission allowances in the first trading period.

Extensive studies both on EUA prices and on EUA derivatives are provided by UhrigHomburg and Wagner (2006a, 2006b) and Seifert et al. (2006). Uhrig-Homburg and Wagner (2006a, 2006b) present results and implications from an expert survey and analyze the relation between EUA spot and futures markets. The expert survey provides an interesting insight into the potential development of derivative instruments on emission allowances, and presents some information about the EU ETS market participants. Covering four main areas of interest in the expert survey (influencing factors of EUA price, fulfillment of basic prerequisites for risk trading in the EU ETS, design issues of EUA derivative instruments, and specific examples of EUA derivatives), the results show that regulatory uncertainties, fuel prices, the fuel price spread, and weather should be considered as the main EUA price drivers. These implications find empirical support in Mansanet-Bataller et al. (2007), MansanetBataller and Pardo (2007), and Alberola et al. (2007), who show that those factors influence the price of EUAs.

Uhrig-Homburg and Wagner (2006b) conclude from the analysis of autocorrelations of EUA returns that the EUA market hardly differs from the market for $\mathrm{SO}_{2}$ allowances in the US (emission allowances in the US cap-and-trade market) or even the more mature DAX market in Germany. Furthermore, they find that the cost-of-carry approach provides a good model for EUA futures prices in the first trading period, but not in the second trading period. Their analysis also suggests that arbitrage possibilities, especially for regulated $\mathrm{CO}_{2}$ emitters, existed until the end of 2005. As regards the information processing on EUA markets, Uhrig-Homburg and Wagner (2006b) find that the futures market leads the price discovery process. Their analysis is based on daily prices but should rather, as noted by the authors, be based on high-frequency data to better trace information processing on EUA markets.

Seifert et al. (2006) present an optimal $\mathrm{CO}_{2}$ abatement strategy of a representative agent within a setup that incorporates the main features of the EU ETS. By using stochastic optimal control theory, the authors derive important characteristics of the EUA spot price process. According to their model, the EUA spot price process should not possess seasonal components and should always be positive with an upper limit that is equal to the discounted penalty costs. Furthermore, the discounted spot price should be a martingale. On the other hand, the volatility of EUAs should increase when approaching the end of the trading period and should reach zero when spot prices are close to EUA price limits. 
An econometric analysis of emission allowance prices is provided by Paolella and Taschini (2006), who focus on the distribution and the return dynamics of emission allowances. Using daily price data of more than six years from the American $\mathrm{SO}_{2}$ emission allowances market and daily price data from the Powernext EUA spot market, the study shows that emission allowance returns have a highly non-Gaussian distribution, as has also been pointed out by Daskalakis et al. (2006) and Benz and Trück (2006b). While Daskalakis et al. (2006) suggest the Chi-squared and the Logistic distribution to model price-level data, Paolella and Taschini (2006) prefer a stableParetian distribution for return data. Paolella and Taschini (2006) combine the Paretian distribution with the GARCH model to analyze the dynamics of EUA returns. In addition, mixed-normal GARCH and mixed-stable-Paretian GARCH models are estimated. According to goodness-of-fit measures, mixed-normal and mixed-stableParetian GARCH models perform much better in modeling of daily EUA volatility than the GARCH(1,1) model of Bollerslev (1986).

Another branch of literature primarily deals with market efficiency in the EU ETS. Apart from the analysis of arbitrage possibilities by Uhrig-Homburg and Wagner (2006b), Daskalakis and Markellos (2007) is the only study that focuses on this issue. In order to assess the weak form of efficiency, the authors analyze the profitability of some trading rules in the EUA market. Their results cast some doubt on the efficiency of EUA trading. Two out of four trading strategies yield positive risk-adjusted returns. These results deserve a closer analysis since data snooping bias may be substantial. ${ }^{5}$ On the other hand, it is not surprising to find violations of the efficient market hypothesis on emerging financial markets like the market for EUAs.

A recent study by Benz and Hengelbrock (2008) focuses on the price discovery and liquidity in the EUA futures market. The results show that ICE Futures/ECX, the exchange with the most liquid trading, leads the on-exchange price discovery process among considered futures markets. Their paper was the first one to use high-frequency data. This work can be considered as an amendment to it.

\section{Data}

Trading in EUA takes place both on organized exchanges and over-the-counter (OTC). The most active trading takes place OTC, with a share of 70 percent of the total daily turnover according to PointCarbon (2008). The remaining 30 percent split up between

\footnotetext{
${ }^{5}$ In a similar set up and based on data for emerging FX markets, Kuang et al. (2008) show that datasnooping bias may be substantial in the analysis of trading rules. Often, many trading rules seem to be profitable. However, there are very few profitable trading rules left after the results are controlled for data-snooping bias. Therefore, the authors find hardly any evidence against the weak form of efficiency on emerging FX markets.
} 
several exchanges, in most cases energy exchanges that also offer trading in electricity, coal, natural gas, crude oil, and other energy related underlyings. Besides an active EUA spot market there is also a vital derivatives market, where futures, options, and other derivatives on EUAs are traded. The most liquid EUA spot market is BlueNext in Paris, which attracts circa 70 percent of the total daily turnover of the whole organized spot market. The most liquid futures market is ICE Futures in London, which absorbs circa 90 percent of the daily turnover in EUA futures.

The data used in this paper has been obtained from BlueNext (EUA spot market) and ICE Futures (EUA futures market). These markets will herein after referred to as EUA spot or EUA futures market. For the spot market, the period under consideration spans all trading days between 24/06/2005 and 01/09/2008. The sample period for the futures market is slightly longer and covers trading days between 22/04/2005 and 01/09/2008. The raw data files contain a total of 247,666 transactions, 8,018 for the spot and 239,648 for the futures market. The data is not equally spaced, since it contains all tickby-tick transactions from the considered markets. In order to give a clear picture about the price formation in the EU ETS, several screening criteria are employed. First, all records that are not on-exchange transactions are removed from the sample. This is done mainly for the futures market on the basis of available trade type indicators. Second, all prices above 40 Euros are also deleted from the sample (relevant for 24 observations). This is done primarily to correct for outliers. These restrictions reduce the sample to 159,475 observations.

\section{Intraday Price Formation of EUAs}

\subsection{Price Formation of EUAs Allocated to the First Commitment Period}

Table 1 reports descriptive statistics on price formation of EUAs that were allocated to the first commitment period. Please note that the trading periods are slightly longer than the commitment periods themselves, since the deadline for submitting EUAs for the preceding years' emissions is always on April 30 of the following year.

The average price on both EUA spot and futures markets moved around 23 euros in the first trading year. In the following years, the average price collapsed as a consequence of the over-allocation of allowances. Most notably, it dropped to three euro cents at the end of the trading phase. The highest activity in the market can be observed for 2006 when an average of 12.52 transactions took place per day on the spot market, and 47.48 transactions on the futures market. By 2007, the average number of daily trades had dropped to 6.38 in the spot market and to 22.67 in the futures market. Table 1 also indicates that the futures market is the more active of the two markets. In 2006, the total 
transaction volume was 1.93 billion euros on the futures market, but only 469 million euros on the spot market.

[insert Table 1 about here]

Although the total trading volume is quite high, some other statistics indicate a low overall activity in both EUA markets as, for example, the average time between two consecutive trades, the total number of transactions per year. In 2006 (the most active year of trading) the average time between two consecutive trades was 26.4 minutes in the spot market and 10.9 minutes in the futures market, respectively. For the other years, these statistics show an even lower activity. Since 2006 the activity has strongly decreased and came to a virtual standstill in 2008. There were only 32 transactions in the futures market and 126 transactions in the spot market in the first four months of 2008. The reason for this is primarily the over-allocation of allowances, but also the exchange fees which for example, based on a transaction price of two euro cents and without considering annual member fees, amount to 100 percent of the EUA spot transaction price. This is a classical example, where exchange fees, or transaction costs in general, place a lower bound on the observable price.

Formal statistical testing shows that the means of price changes are not significantly different from zero in both markets. Figures 1 and 2 display the frequencies of price changes, measured in euros, as a function of tick size. The shape of the frequency distributions for the spot market is quite puzzling, at least at first glance. There are very large spikes at price changes that are positive or negative multiples of five euro cents and yet the minimum tick size is only one euro cent. In particular, since the start of trading, BlueNext's minimum EUA spot market price movements are one euro cent, see Powernext (2006). ${ }^{6}$ In contrast to the EUA spot market, EUA futures prices were initially only allowed to move by a minimum of five euro cents. On 27/03/2007, however, ICE Futures decreased the minimum tick size of the EUA futures contracts to one euro cent. Therefore, one possible explanation for this anomaly is the strong link between the spot market and the futures market where the minimum tick size was five euro cents until March 2007. Consistent with this explanation is the fact that in 2007, when the minimum tick size on the futures market decreased to one euro cent, those spikes virtually disappeared. However, an alternative explanation for the disappearance of spikes in the distribution of 2007 is the fact that by 2007 the average price had dropped to a value of less than two euro cents (see Table 1) and prices remained on a

\footnotetext{
${ }^{6}$ BlueNext is the former Powernext's spot carbon market, see www.BlueNext.eu.
} 
low level throughout the year. Therefore, it is very unlikely to see price changes that are positive or negative multiples of five euro cents for 2007.

[insert Figure 1 about here]

[insert Figure 2 about here]

Frequencies of prices changes in the futures market are displayed in Figure 2. The frequency distribution is roughly symmetrical and centered around zero. For the years 2005 and 2006, the price discreteness of five euro cents is obvious. Spikes in the empirical distribution of EUA futures price changes are observed in the frequency distribution for 2007. This is due to the fact that the minimum tick size was reduced to one euro cent in March 2007. The bottom left part of Figure 2 can be regarded as a mixture of two distributions with identical means but different variances. Yet, spikes in the distribution of EUA price changes are observable when we only use price changes after the introduction of the new price discreteness scheme. ${ }^{7}$

\subsection{Price Formation of EUAs Allocated to the Second Commitment Period}

Table 2 reports descriptive statistics on price formation of EUAs that were allocated to the second commitment period. Please note that spot trading of EUAs that were allocated to the second commitment period began in 2008, while trading of correspondent futures started in 2005.

Comparable to the first commitment period, the EUA futures market in the second commitment period is again by far more liquid than the EUA spot market. We will restrict ourselves to commenting only on the EUA futures market due to space restrictions. Since 2005 the price of EUAs, which are to be delivered or to be received in December 2008, has ranged between 12 and 34 euros. The average daily number of transactions rose from 1.84 in 2005 to 518.39 in 2008. However, in the same period, the average transaction volume decreased from circa 14 thousand EUAs in 2005 to circa 5 thousand in 2008, or expressed in euros, from circa 299 thousand euros in 2005 to circa 113 thousand euros in 2008. Although the overall activity in this market strongly increased since 2005, it seems that a transition took place from big to small order

\footnotetext{
${ }^{7}$ Due to space restrictions and strong similarity to the bottom left part of Figure 2, we do not display the frequency distribution of price changes in this sub-period of 2007. Note that for 2008 there are only 32 transactions in EUA futures (March 2008 futures contract) for the first commitment period in our sample. For reasons of symmetry we include the frequency distribution of that year, although it is clearly not very informative.
} 
volumes. The increase in market activity is reflected in the average time between two consecutive trades, which decreased from 43.1 minutes in 2005 to 1.1 minutes in 2008.

[insert Table 2 about here]

Figure 3 shows the frequency distributions of price changes of the December 2008 futures contract for the years 2005 to 2008. All four distributions have a mode of zero. The distributions for 2006, 2007 and 2008 are roughly symmetrical. The fat tails, which are a familiar stylized fact of financial markets, are indicative of extremely positive and negative price movements. Again, it is puzzling that the distribution of price changes in 2007 has strong spikes at positive and negative multiples of five euro cents when the minimum tick size for futures contracts was reduced to one euro cent in March 2007.

[insert Figure 3 about here]

These spikes, especially for spot markets in the years of 2005 and 2006 (see Figure 1) are anomalies that are not easy to explain. As mentioned above, it appears that the inherent connection between considered EUA spot and EUA futures markets and temporary different price discreteness in both markets are responsible for the spikes. In particular, the price discreteness in the EUA futures market appears to influence the price discreteness in the EUA spot market. The connection between both markets seems to be present even nowadays, since the multiples of five euro cents are still present in the EUA futures (see the price distribution for 2008) and even in the EUA spot market in 2008 (see Figure 7 in the appendix). A supportive argument for the spikes in the EUA futures market would be that there are still many market participants who quote their orders according to the former minimum price change scheme of five euro cents. This might be due to several reasons, e.g. a preference for round numbers, convenience, or even coordination on coarse price sets as suggested by Harris (1991). Another reason could be that competition among market participants is not strong enough, neither in the EUA futures nor in the EUA spot market - almost one year after the reduction of the minimum price change to one euro cent.

\section{Volatility of EUA Returns}

The volatility of EUAs has already attracted some interest in the literature and has been modelled by ARCH models; see for instance Benz and Trück (2006b) or Paolella and Taschini (2006). However, there is no literature on the estimation of EUA volatility 
itself. To close this gap, this section provides some unreported features of the EUA intraday volatility pattern. Moreover, different EUA volatility estimates are presented, using recently proposed volatility measures, and are then compared to classical volatility estimates.

The analysis of EUA volatility is performed by means of log-returns, or returns as called in the following. The returns are defined as the first difference of the logarithms of two prices that are separated by a five-minute interval. The construction of equidistant prices largely follows Andersen and Bollerslev (1997). Most notably, the analysis uses transaction prices instead of mid-quotes and equidistant intervals of 5 minutes. The equidistant price is calculated for each 5-minute interval during the trading session as the mean of the preceding and immediately following prices. The distance of the transaction prices from the equidistant point in time is not applied in the calculation.

\subsection{Intraday Volatility of EUA Returns}

In classically organized financial markets, for example in well-established equity markets, intraday volatility is relatively high at the market opening and market closing, and low around midday. It follows a so-called "U-shaped” pattern. This characteristic of organized financial markets is well-known and has been documented for instance in Harris (1986). The intraday volatility of EUAs evolves quite differently throughout the trading day. However, one has recently been able to discern a rudimental U-shaped pattern in the shape of the intraday volatility.

The average absolute EUA log-returns over five-minute intervals in the EUA spot and futures market, that are used to approximate intraday volatility, are illustrated in Figure 4. Said figure indicates that intraday volatility of EUAs varies substantially throughout the day both in the spot and futures market. This result is confirmed by the Bartlett test, which tests the hypothesis that the volatilities of different time intervals within the trading day are equal. ${ }^{8}$ The hypothesis is rejected at any conventional significance levels for all considered markets. ${ }^{9}$

8 The Bartlett Test tests the hypothesis $\sigma_{1}^{2}=\sigma_{2}^{2}=\ldots=\sigma_{k}^{2}=\sigma^{2}$, where subscripts represent the appropriate time intervals during the day. The test is based on the following statistic

$$
M=\frac{\sum_{j=1}^{k}\left(n_{j}-1\right)\left[\ln S_{j}^{2}-\ln \hat{S}^{2}\right]}{1+1 / 3(k-1)\left[\sum_{j=1}^{k}\left(1 / n_{j}-1\right)-(1 / N-k)\right]} \text {, with } S_{j}^{2}=\frac{1}{n_{j}-1} \sum_{i=1}^{n_{j}}\left(r_{k, i}-\bar{r}_{k}\right)^{2} \text { and } \hat{S}^{2}=\frac{\sum_{j=1}^{k}\left(n_{j}-1\right) S_{j}^{2}}{N-k} \text {. }
$$

$k$ is the total number of intervals during the day. Each $\mathrm{k}$ with $1,2,3, \ldots, j$ has $n_{j}$ observations. $N$ is the total number of observations. Under the null hypothesis, the $\mathrm{M}$ statistic follows a chi-square distribution with $k-1$ degrees of freedom.

${ }^{9}$ The M statistic has the following values: 57,640 (Spot Phase I), 249,849 (Spot Phase II), 59,916 (Futures Phase I), 355,021 (Futures Phase II). The appropriate critical values at the 5 percent significance level are: 650.76, 126.57, 706.23, and 199.24. k equals 96 (120) in the case of spot (futures) markets. 
The pattern of EUA intraday volatility is quite different from that of classically organized financial markets. In general, the EUA intraday volatility starts at relatively low levels. It then rises to a peak within first trading hours before dropping to a fairly low level again. Similarly to classical financial markets, the volatility level rises slightly before the end of the trading session. Pronounced changes also occur in the pattern observed. When considering only transactions in the EUA futures market in 2008, there is rudimental evidence for a U-shaped pattern, especially at the beginning of the trading session (see Figure 8 in the appendix). However, there is still no pronounced increase of volatility at the end of a trading day.

[insert Figure 4 about here]

According to these simple graphical tools, information processing within a trading day in the EU ETS has changed since the very beginning of 2005. It is reasonable to conclude that at that time, little new information occurred between two consecutive trading days, since EUA intraday volatility used to be relatively low at market opening. However, it seems that now new information does indeed occur between two consecutive trading days. Market participants take this into account by adjusting their positions immediately after market opening. For this reason, the whole EUA intraday volatility pattern seems to converge to a U-shape pattern, despite the divergence at market closure. Given these results, the intraday trading of EUAs does not yet function as expected, as is e.g. the case for organized equity markets.

\subsection{Daily Volatility of EUA Returns}

The simplest method for estimating the volatility of returns is to use squared or absolute returns. For instance, the ex-post volatility of a given day is simply measured by its squared or absolute return. A more sophisticated method involves computing realized volatility, as recently proposed by Andersen et al. (2003) or Barndorff-Nielsen and Shephard (2002). Realized volatility over a trading day is defined as the sum of highfrequency intraday squared returns, e.g. five-minute returns:

$$
R V_{t}(h)=\sum_{j=1}^{M} r_{t, j}^{2}(h), \quad \text { for } \quad t=1, \ldots, T
$$

where $r(h)_{t, j}$ represents the intraday log-return on day $t$ in the $j$-th intraday period. Intraday returns are sampled at the frequency $h . M$ is the number of intraday returns per trading day and depends on the time interval $h$. For instance, setting $h$ to five 
minutes leads to $M=96$ if there are eight trading hours per day. $T$ is the total number of trading days. Realized volatility represents a simple ex-post volatility measure that converges in probability, and under fairly general conditions, to the latent and unobservable return volatility over the relevant horizon (integrated volatility; in this case daily volatility) as $h \rightarrow 0$. Daily realized volatility calculated via high-frequency returns represents a more precise measure of daily integrated volatility than daily squared or absolute returns, and is, moreover, easy to implement. For the sake of comparison, we also use realized standard deviation and logarithmic realized standard deviation to approximate the volatility of EUA returns. The realized standard deviation for day $t$ is defined as the square root of the realized volatility for the same day, $r v_{t}=\left(R V_{t}(h)\right)^{1 / 2}$. Logarithmic realized standard deviation is defined as the natural logarithm of $r v_{t}$. In addition, realized volatility measures are compared to daily squared returns and daily absolute returns.

The calculation and comparison of volatility estimates is based on data from the EUA futures market that refer to the December 2008 futures contract. Estimates of volatility of EUAs that were allocated to the first commitment period will not be considered because this market collapsed. As a result, volatility estimates calculated with price data from this market are blurred, most notably because of the low prices at the end of the sample period.

[insert Table 3 about here]

The following results are presented for daily volatility estimates, and concentrate on five estimates: squared daily returns, daily realized volatility, absolute daily returns, daily realized standard deviation, and logarithmic realized standard deviation. The estimates are calculated either with five-minute or with daily returns. Since there are 10 trading hours per trading day $(6.00$ - 16.00 GMT) in the considered EUA futures market, realized-volatility estimates are calculated using 120 equidistant observations per day. In total there are 647 trading days in our sample.

Descriptive statistics of the volatility estimates are summarized in Table 3. Four volatility estimates are leptokurtic and skewed to the right. The fact that the distribution of volatility estimates are skewed to the right is not surprising, since all volatility estimates have a lower boundary at zero, apart from the logarithmic realized standard deviation. The unconditional distribution of logarithmic realized standard deviation appears to be largely Gaussian. The most remarkable summary statistics are the maximum values. The maxima of squared daily returns and of realized volatility are approximately 90 times their mean, and the maxima of absolute returns and realized 
standard deviation reach values of around 15 times their mean. Despite that the data was corrected for outliers and given that the calculation of equidistant prices already eliminates many extreme values, several extreme prices remain. These results already suggest that EUA volatility exhibits erratic movements.

The time-series estimates of the four volatility estimators are displayed in Figure 5 (the visualization of logarithmic realized standard deviation has been omitted to save space). In the sub-figures we do not display values above 0.025 (for squared returns) and 0.01 (for realized volatility) and 0.5 (for absolute returns and realized standard deviation) in order to provide a closer look at the dynamics of volatility. All four graphs show that EUA volatility exhibits extreme values for several days, independent of the specific volatility measure. Furthermore, the realized volatility estimates often have more extreme values than squared or absolute daily EUA returns. This indicates a substantial intra-day variability of futures prices. Another peculiarity of volatility is also observable, namely the volatility clusters. As in other financial markets, the EUA volatility gradually increases or decreases for several periods.

[insert Figure 5 about here]

\subsection{Dynamic Dependence of Daily Volatility of EUA Returns}

The empirical autocorrelation function (ACF), the simplest measure of autocorrelation of daily volatility of EUA returns, is visualized in Figure 6. Further dependence statistics are summarized in Table 4. The ACF shows that there is virtually no autocorrelation in squared returns (top right figure). Only one coefficient (lag 13) is significantly different from zero at the 5 percent significance level. At this significance, it is reasonable to expect that under the null hypothesis one out of twenty coefficients exceeds the critical values. For the realized volatility (top right figure) there are five coefficients (lag $1,2,11,12,13$ ) that are significantly different from zero at the 5 percent significance level. For absolute daily EUA returns, realized standard deviation, as well as for logarithmic realized standard deviation (solid line in the bottom right figure), most of the coefficients up to lag 20 are significantly different from zero.

[insert Figure 6 about here] 
The calculation of the ACF for several sub-samples, in particular for several calendar years, reveals that the autocorrelation is not stable. ${ }^{10}$ However, in most cases, the overall picture remains. For example, in 2007, the ACFs of realized volatility measures have significant coefficients at the 5 percent level up to lag 15 . In addition, they exhibit slow decay. The significance of the first-order autocorrelation coefficient in daily squared and absolute returns is more present in the sub-samples than in the full sample. However, there is no evidence for a pronounced slow decay of their ACFs in any subsample. Furthermore, the structure of the ACF of squared and absolute daily returns does not change when we use daily average prices to construct daily squared or absolute EUA returns. In contrast to realized volatility or realized standard deviation, logarithmic realized standard deviation exhibits a more persistent dynamic dependence structure. All autocorrelation coefficients up to and including lag 20 are significantly different from zero at the 5 percent significance level. Their numerical values are, in most cases, larger than those of daily squared or absolute returns.

These results partly suggest a long-memory property of EUA volatility, which is also supported by the dynamic volatility dependence measures shown in Table 4. In particular, the Geweke-Porter-Hudak estimator $d$ shows a fractional integration of EUA volatility for most considered volatility measures. The estimated fractional integration parameter for all considered measures is positive and equals to values that range from 0.21 to 0.39 . The three estimates derived from realized volatility measures are clearly significantly different from zero. Three out of five measures show a value between 0.30 and 0.40 - the degree of fractional integration that is often estimated for dynamic volatility dependence in classical financial markets. The Augmented DickeyFuller test suggests a stationary EUA volatility process, since the hypothesis of a unit root is rejected at conventional significance levels for all volatility estimates. Finally, the Ljung-Box portmanteau test statistic shows that the hypothesis of no autocorrelation up to and including lag 20 is rejected for all considered volatility estimates.

In contrast to the literature on the volatility estimation of returns, normality tests reject the hypothesis of a normal distribution for the EUA logarithmic realized standard deviation. Detailed results are displayed in Table 5.

[insert Table 4 about here]

\footnotetext{
${ }^{10}$ The subsamples cover the following periods: 05/07/2005 - 30/11/2005, 10/01/2006 - 29/12/2006, 02/01/2007 - 31/12/2007, 02/01/2008 - 01/09/2008.
} 
In summary, the majority of the dependence measures point to a long-memory property of realized volatility measures and daily squared/absolute EUA returns. This is consistent with the literature on volatility estimation, even though the long-memory property is not supported by the ACF of daily squared EUA returns. Given these results, it is reasonable to conclude that the dynamics of volatility of daily EUA returns can be appropriately captured by fractional long-memory processes. However, according to the dynamics in Figure 5, EUA volatility may possess jumps, as suggested by Daskalakis et al. (2006). Finally, in most studies, logarithmic realized standard deviation is found to be normally distributed, which is not the case for our data.

[insert Table 5 about here]

\section{Conclusions}

This paper investigates price dynamics and volatility in the European Union Emissions Trading Scheme (EU ETS) using high frequency data. The results show that the activity in the on-exchange market for EUAs allocated to the first commitment period (2005 2007) was highest in 2006, the year in which information about possible over-allocation was released for the first time. In 2007, trading activity plunged. In contrast, trading in EUAs allocated to the second commitment period (2008 - 2012) has increased since the official start of the EU ETS in 2005. For instance, the average time between two consecutives transactions in this market decreased from 43.1 minutes in 2005 to 1.1 minutes in the first eight months of 2008. Moreover, the results show that the price discreteness in the EUA spot market (BlueNext) seems to be strongly affected by the price discreteness of the EUAs futures market (ICE Futures), supporting the strong relation between these markets; which appears to be even stronger than reported in the recent literature. Currently, the price discreteness schemes are identical in the spot and futures markets. ICE Futures lowered the minimum tick size of EUAs futures from 5 euro cents to 1 euro cent in March 2007. However, we are still confronted with the puzzling fact that in this market, price movements of 5 euro cents are more frequent than price movements of 3 or 4 euro cents.

The analysis of the intraday volatility shows that activity in the EUA markets is not constant throughout the trading day. Intraday volatility rises from low levels to high levels around 11:00 GMT. The typical U-shaped pattern of intraday volatility often observed in organized financial markets is partly present in the EUA futures market in 2008. Similar to other classical financial markets, the realized volatility estimates of daily EUA volatility appear to have a long-memory property. The logarithmic realized standard deviation of EUA returns exhibits a more persistent dynamic dependence 
structure than realized volatility, realized standard deviation, or daily squared/absolute EUAs returns. The often observed normality of logarithmic realized standard deviation, however, can not be confirmed.

Several open questions remain for further research. First of all, the strong relation between the EUA spot und EUA futures markets deserves a thorough analysis, since the dependence might be even stronger than previously reported. Furthermore, market efficiency must be analyzed with high-frequency data and the use of more sophisticated methods, since eyeball econometrics does not suffice to make firm statements about the functioning of the EU ETS at the micro level. Finally, the apparent long-memory property of EUA volatility deserves a modeling via fractional long-memory processes. 


\section{References}

Alberola, É., Chevallier, J., Chèze, B. (2007), European Carbon Prices Fundamentals in 2005-2007: The Effects of Energy Markets, Temperatures and Sectorial Production, Working Paper, Université Paris X Nanterre.

Andersen, T.G., Bollerslev, T. (1997), Intraday Periodicity and Volatility Persistence in Financial Markets, Journal of Empirical Finance, 4, 115-158.

Andersen, T.G., Bollerslev, T., Diebold, F.X., Labys P. (2003), Modeling and Forecasting Realized Volatility, Econometrica, 71 (2), 579-625.

Barndorff-Nielsen, O.E., Shephard, N. (2002), Econometric Analysis of Realized Volatility and Its Use in estimating Stochastic Volatility Models, Journal of Royal Statistical Society, 64 (2), 253-280.

Bayer, D., Borell, M., Moslener, U. (2006), Quantifying Liquidity in Emissions Allowance Markets: Issues and Perspectives, unpublished ZEW-Discussion Paper, Mannheim.

Benz, E., Hengelbrock, J, (2008), Price Discovery and Liquidity in the European $\mathrm{CO}_{2}$ Futures Market: An Intraday Analysis. Available at SSRN: http://ssrn.com/abstract=1283175.

Benz, E., Trück, S. (2006a), $\mathrm{CO}_{2}$ Emission Allowances Trading in Europe - Specifying a new Class of Assets, Problems and Perspectives in Management, 4 (3), 3040.

Benz, E., Trück, S. (2006b), Modelling $\mathrm{CO}_{2}$ Emission Allowance Prices, Working Paper, Bonn Graduate School of Economics, Germany, Queensland University of Technology, Australia.

Boehringer, C., Hoffmann, T., Lange, A., Löschel, A., Moslener, U. (2005), Assessing Emissions Regulation in Europe: An Interactive Simulation Approach, Energy Journal, 26 (4), 1-22.

Bollerslev, T. (1986), Generalized Autoregressive Conditional Heteroskedasticity, Journal of Econometrics, 31, 307-327.

Borak, S., Haerdle, W., Trück, S., Weron, R. (2006), Convenience Yields for $\mathrm{CO}_{2}$ Emission Allowance Futures Contracts, SFB 649 Discussion Paper 2006-076, Humboldt-Universität zu Berlin.

Cramton, P., Kerr, S. (2002), Tradable Carbon Permit Auctions: How and why to Auction not Grandfather? Energy Policy, 30 (4), 333-345.

Daskalakis, G., Psychoyios, D., Markellos, R.N. (2006), Modeling $\mathrm{CO}_{2}$ Emission Allowance Prices and Derivatives: Evidence from the European Markets, Working Paper, Athens University of Economics and Business. 
Daskalakis, G., Markellos, R.N. (2007), Are the European Carbon Markets Efficient? Working Paper, Athens University of Economics and Business.

European Parliament and Council (2003), Directive 2003/87/EC of the European Parliament and of the Council of 13 October 2003. Official Journal of the European Union, L 275, 32-46.

Harris, L. (1986), A Transaction Data Study of Weekly and Intradaily Patterns in Stock Returns, Journal of Financial Economics, 16, 99-117.

Harris, L. (1991), Stock Price Clustering and Discreteness, Review of Financial Studies, 4, 389-415.

Klepper, G., Peterson, S. (2004), The EU Emissions Trading Scheme, Allowance Prices, Trade Flows, Competitiveness Effects, European Environment, 14 (4), 201-218.

Kruger, J.A., Pizer, W.A. (2004), Greenhouse Gas Trading in Europe. The New Grand Policy Experiment, Environment, 46, 8-23.

Kuang, P., Schröder, M. Wang, Q. (2008), Trading Rules Profitability in the Emerging FX Market: Danger of Data Snooping, Unpublished ZEW-Discussion Paper, Mannheim.

Mansanet-Bataller, M., Pardo, A., Valor i Micó, E. (2007), $\mathrm{CO}_{2}$ Prices, Energy and Weather, Energy Journal, 28 (3), 73-92.

Mansanet-Bataller, M., Pardo, A. (2007), The Effects of National Allocation Plans on Carbon-Markets, Working Paper, Faculty of Economics, University of Valencia, Valencia.

Moslener, U. (2007), Was treibt die Strompreise? Schwerpunkt Energiemarkt, Sonderteil ZEWnews, Januar/ Februar, Zentrum für Europäische Wirtschaftsforschung (ZEW), Mannheim.

Oberndorfer, U., Rennings, K. (2006), The Impacts of the European Union Emissions Trading Scheme on Competitiveness in Europe, ZEW Discussion Paper No. 06-51, Mannheim.

Paolella, M.S., Taschini, L. (2006), An Econometric Analysis of Emission Trading Allowances, Working Paper, University of Zurich and University of Zürich Swiss Banking Institute.

PointCarbon (2006a), "Dutch emissions fewer than expected in '05", 24.04.2006. Available at PointCarbon: http://www.pointcarbon.com/news/1.18431.

PointCarbon (2006b), “Czech ETS companies emit 15 per cent less than allocated in 2005”, 25.04.2006. Available at PointCarbon: http://www.pointcarbon.com/news/1.18439. 
PointCarbon (2008), Carbon 2008, Post-2012 is Now. Point Carbon's $5^{\text {th }}$ annual conference: Carbon Market Insights 2008, Copenhagen.

Powernext (2006), Powernext Carbon - An Organised Market to Fight Climate Change, Paris.

Seifert, J., Uhrig-Homburg, M., Wagner, M.W. (2006), Dynamic Behavior of $\mathrm{CO}_{2}$ Spot Prices - Theory and Empirical Evidence, Working Paper, Universität Karlsruhe (TH).

Sijm, J.P.M., Chen, Y., ten Donkelaar, M., Hers, J.S., Scheepers, M.J.J. (2006), $\mathrm{CO}_{2}$ Price Dynamics: A Follow-up Analysis of the Implications of EU emissions Trading for the Price of Electricity, ECN-C—06-015, Energy research Centre of the Netherlands (ECN), Petten/Amsterdam.

Uhrig-Homburg, M., Wagner, M.W. (2006a), Market Dynamics and Derivative Instruments in the EU Emissions Trading Scheme - an Early Market Perspective, Working Paper, Universität Karlsruhe (TH).

Uhrig-Homburg, M., Wagner, M.W. (2006b), Forward Price Dynamics of CO2 Emission Certificates - an Empirical Analysis, Working Paper, Universität Karlsruhe (TH). 


\section{Appendix}

[insert Figure 7 about here]

[insert Figure 8 about here] 


\section{Tables}

Table 1: Summary statistics of on-exchange transactions

\begin{tabular}{|c|c|c|c|c|}
\hline \multicolumn{5}{|c|}{ 1. Commitment Period ${ }^{11}$} \\
\hline \multicolumn{5}{|c|}{ EUA Spot Market } \\
\hline Trading year & 2005 & 2006 & 2007 & $2008 *$ \\
\hline Instrument & EUAs & EUAs & EUAs & EUAs \\
\hline Maximum price & 29.25 & 30.00 & 6.40 & 0.05 \\
\hline Average price & 22.33 & 16.19 & 1.69 & 0.02 \\
\hline Minimum price & 18.05 & 6.25 & 0.02 & 0.01 \\
\hline Average daily number of transactions & 5.74 & 12.52 & 6.38 & 3.00 \\
\hline Average transaction volume (in EUAs) & 6,609 & 10,156 & 19,239 & 42,008 \\
\hline Average transaction volume (in EUR) & 147,144 & 153,584 & 25,841 & 1,056 \\
\hline $\begin{array}{l}\text { Average time between two consecutive } \\
\text { trades (in minutes) }\end{array}$ & 30.2 & 26.4 & 37.7 & 29.6 \\
\hline Total number of transactions & 660 & 3,055 & 1,232 & 126 \\
\hline Total transaction volume (in Mio. EUAs) & 4.36 & 31.00 & 23.70 & 5.29 \\
\hline Total transaction volume (in Mio. EUR) & 97.10 & 469.00 & 31.80 & 0.13 \\
\hline \multicolumn{5}{|c|}{ EUA Futures Market } \\
\hline Trading year & 2005 & 2006 & 2007 & $2008 * *$ \\
\hline Instrument & $\begin{array}{l}\text { Dec } 2005 \\
\text { Futures } \\
\text { contract } \\
\end{array}$ & $\begin{array}{c}\text { Dec } 2006 \\
\text { Futures } \\
\text { contract } \\
\end{array}$ & $\begin{array}{c}\text { Dec } 2007 \\
\text { Futures } \\
\text { contract } \\
\end{array}$ & $\begin{array}{c}\text { March } 2008 \\
\text { Futures } \\
\text { contract }\end{array}$ \\
\hline Maximum price & 29.50 & 31.00 & 6.50 & 0.03 \\
\hline Average price & 22.70 & 17.61 & 1.85 & 0.01 \\
\hline Minimum price & 15.75 & 6.30 & 0.01 & 0.01 \\
\hline Average daily number of transactions & 18.04 & 47.48 & 22.67 & 3.20 \\
\hline Average transaction volume (in EUAs) & 7,737 & 8,747 & 10,510 & 52,344 \\
\hline Average transaction volume (in EUR) & 176,202 & 165,103 & 13,645 & 712 \\
\hline $\begin{array}{l}\text { Average time between two consecutive } \\
\text { trades (in minutes) }\end{array}$ & 24.4 & 10.9 & 13.4 & 57.0 \\
\hline Total number of transactions & 2,959 & 11,679 & 4,783 & 32 \\
\hline Total transaction volume (in Mio. EUAs) & 23.00 & 102.00 & 50.30 & 0.30 \\
\hline Total transaction volume (in Mio. EUR) & 523.00 & $1,930.00$ & 65.30 & 0.003 \\
\hline
\end{tabular}

Source: BlueNext, ICE Futures. * until 24/04/2008, ** until 31/03/2008. Own calculations.

11 Although the first commitment period spans three years from 2005 to 2007, the first trading period lasted until 30/04/2008, when the deadline for submissions of EUAs for the preceding years' emissions became effective. 
Table 2: Summary statistics for EUAs allocated to the second commitment period

\begin{tabular}{|c|c|c|c|c|}
\hline \multicolumn{5}{|c|}{ 2. Commitment Period } \\
\hline \multicolumn{5}{|c|}{ EUA Spot Market } \\
\hline Trading year & 2005 & 2006 & 2007 & $2008 *$ \\
\hline Instrument & EUAs & EUAs & EUAs & EUAs \\
\hline Maximum price & & \multirow{10}{*}{ No trading. } & & 29.15 \\
\hline Average price & & & & 24.67 \\
\hline Minimum price & & & & 20.35 \\
\hline Average daily number of transactions & & & & 28.02 \\
\hline Average transaction volume (in EUAs) & & & & 11,528 \\
\hline Average transaction volume (in EUR) & & & & 282,179 \\
\hline $\begin{array}{l}\text { Average time between two consecutive } \\
\text { trades (in minutes) }\end{array}$ & & & & 14.2 \\
\hline Total number of transactions & & & & 2,886 \\
\hline Total transaction volume (in Mio. EUAs) & & & & 33.30 \\
\hline Total transaction volume (in Mio. EUR) & & & & 814.00 \\
\hline \multicolumn{5}{|c|}{ EUA Futures Market } \\
\hline Trading year & 2005 & 2006 & 2007 & $2008 *$ \\
\hline Statistic / Instrument & $\begin{array}{c}\text { Dec } 2008 \\
\text { Futures } \\
\text { contract } \\
\end{array}$ & $\begin{array}{c}\text { Dec } 2008 \\
\text { Futures } \\
\text { contract }\end{array}$ & $\begin{array}{c}\text { Dec } 2008 \\
\text { Futures } \\
\text { contract } \\
\end{array}$ & $\begin{array}{c}\text { Dec } 2008 \\
\text { Futures } \\
\text { contract } \\
\end{array}$ \\
\hline Maximum price & 29.90 & 33.70 & 26.00 & 29.69 \\
\hline Average price & 21.40 & 18.41 & 20.54 & 24.01 \\
\hline Minimum price & 17.60 & 14.75 & 11.80 & 18.60 \\
\hline Average daily number of transactions & 1.84 & 16.76 & 159.14 & 518.39 \\
\hline Average transaction volume (in EUAs) & 13,857 & 9,558 & 6,952 & 4,673 \\
\hline Average transaction volume (in EUR) & 298,950 & 179,985 & 140,815 & 112,503 \\
\hline $\begin{array}{l}\text { Average time between two consecutive } \\
\text { trades (in minutes) }\end{array}$ & 43.1 & 19.8 & 3.5 & 1.1 \\
\hline Total number of transactions & 35 & 3,402 & 40,741 & 87,608 \\
\hline Total transaction volume (in Mio. EUAs) & 0.49 & 32.50 & 283.00 & 409.00 \\
\hline Total transaction volume (in Mio. EUR) & 10.50 & 612.00 & $5,740.00$ & $9,860.00$ \\
\hline
\end{tabular}

Source: BlueNext, ICE Futures. * until 01/09/2008.

Table 3: Summary statistics of five EUA volatility estimates

\begin{tabular}{|l|c|c|c|c|c|}
\hline \multicolumn{7}{|c|}{ EUAs Futures market (December 2008 Futures contract) } \\
\hline $\begin{array}{c}\text { Statistic / } \\
\text { Estimate }\end{array}$ & Squared Returns & $\begin{array}{c}\text { Realized } \\
\text { Volatility }\end{array}$ & Absolute Returns & $\begin{array}{c}\text { Realized } \\
\text { Standard } \\
\text { Deviation }\end{array}$ & $\begin{array}{c}\text { Logarithmic } \\
\text { Realized } \\
\text { Standard } \\
\text { Deviation }\end{array}$ \\
\hline Observations & 646 & 647 & 646 & 647 & 647 \\
\hline NAs & 0 & 0 & 0 & 0 & 3 \\
\hline Maximum & 0.13345 & 0.18659 & 0.36531 & 0.43196 & -0.83943 \\
\hline Mean & 0.00134 & 0.00207 & 0.0224 & 0.03085 & -3.70184 \\
\hline Minimum & 0 & 0 & 0 & 0 & -6.37929 \\
\hline Median & 0.00024 & 0.00057 & 0.01549 & 0.0239 & -3.73273 \\
\hline $\begin{array}{l}\text { Standard } \\
\text { Deviation }\end{array}$ & 0.00756 & 0.01116 & 0.02894 & 0.0335 & 0.62355 \\
\hline Skewness & 15.13229 & 12.68527 & 6.00111 & 7.09983 & 0.27602 \\
\hline Kurtosis & 249.0829 & 176.41295 & 58.27367 & 67.22536 & 3.14621 \\
\hline
\end{tabular}

Source: BlueNext, ICE Futures. Own calculations. 
Table 4: Dynamic dependence measures for four volatility estimates

\begin{tabular}{|l|c|c|c|c|c|}
\hline \multicolumn{1}{|c|}{$\begin{array}{c}\text { Statistic / } \\
\text { Estimate }\end{array}$} & $\begin{array}{c}\text { Squared } \\
\text { Returns }\end{array}$ & $\begin{array}{c}\text { Absolute } \\
\text { Returns }\end{array}$ & $\begin{array}{c}\text { Realized } \\
\text { Volatility }\end{array}$ & $\begin{array}{c}\text { Realized } \\
\text { Standard } \\
\text { Deviation }\end{array}$ & $\begin{array}{c}\text { Logarithmic } \\
\text { Realized } \\
\text { Standard } \\
\text { Deviation }\end{array}$ \\
\hline$d_{G P H}$ & 0.2177 & 0.3361 & 0.2125 & 0.3572 & 0.3908 \\
\hline $\begin{array}{l}\text { Standard error } \\
\text { of } d_{G P H}\end{array}$ & 0.1390 & 0.1340 & 0.0531 & 0.0794 & 0.1751 \\
\hline$A D F$ & -7.51 & -5.80 & -7.31 & -5.57 & -4.34 \\
\hline P-value & $<0.01$ & $<0.01$ & $<0.01$ & $<0.01$ & $<0.01$ \\
\hline$Q(20)$ & 42.32 & 296.90 & 294.18 & 738.07 & 160.47 \\
\hline P-value & $<0.01$ & $<0.01$ & $<0.01$ & $<0.01$ & $<0.01$ \\
\hline
\end{tabular}

$d_{G P H}$ represents the Geweke-Porter-Hudak estimator of the fractional integration parameter $d$. ADF represents the Augmented Dickey-Fuller test statistic that was calculated using lag order eight, and $Q(20)$ represents the Ljung-Box test statistic for the hypothesis of no autocorrelation up to and including lag 20.

Table 5: Normality tests for logarithmic realized standard deviation

\begin{tabular}{|c|c|c|c|c|}
\hline Statistic/Estimate & Jarque-Bera Test & $\begin{array}{c}\text { Shapiro-Wilk } \\
\text { Normality-Test }\end{array}$ & $\begin{array}{c}\text { One-sample } \\
\text { Kolmogorov- } \\
\text { Smirnov-Test }\end{array}$ & $\begin{array}{c}\text { Anderson-Darling } \\
\text { Normality-Test }\end{array}$ \\
\hline Test statistic & 277.07 & 0.9539 & 0.9707 & 6.8467 \\
\hline P-value & $<0.01$ & $<0.01$ & $<0.01$ & $<0.01$ \\
\hline
\end{tabular}




\section{Figures}

Figure 1: Empirical distribution of price changes in the EUA spot market (BlueNext)
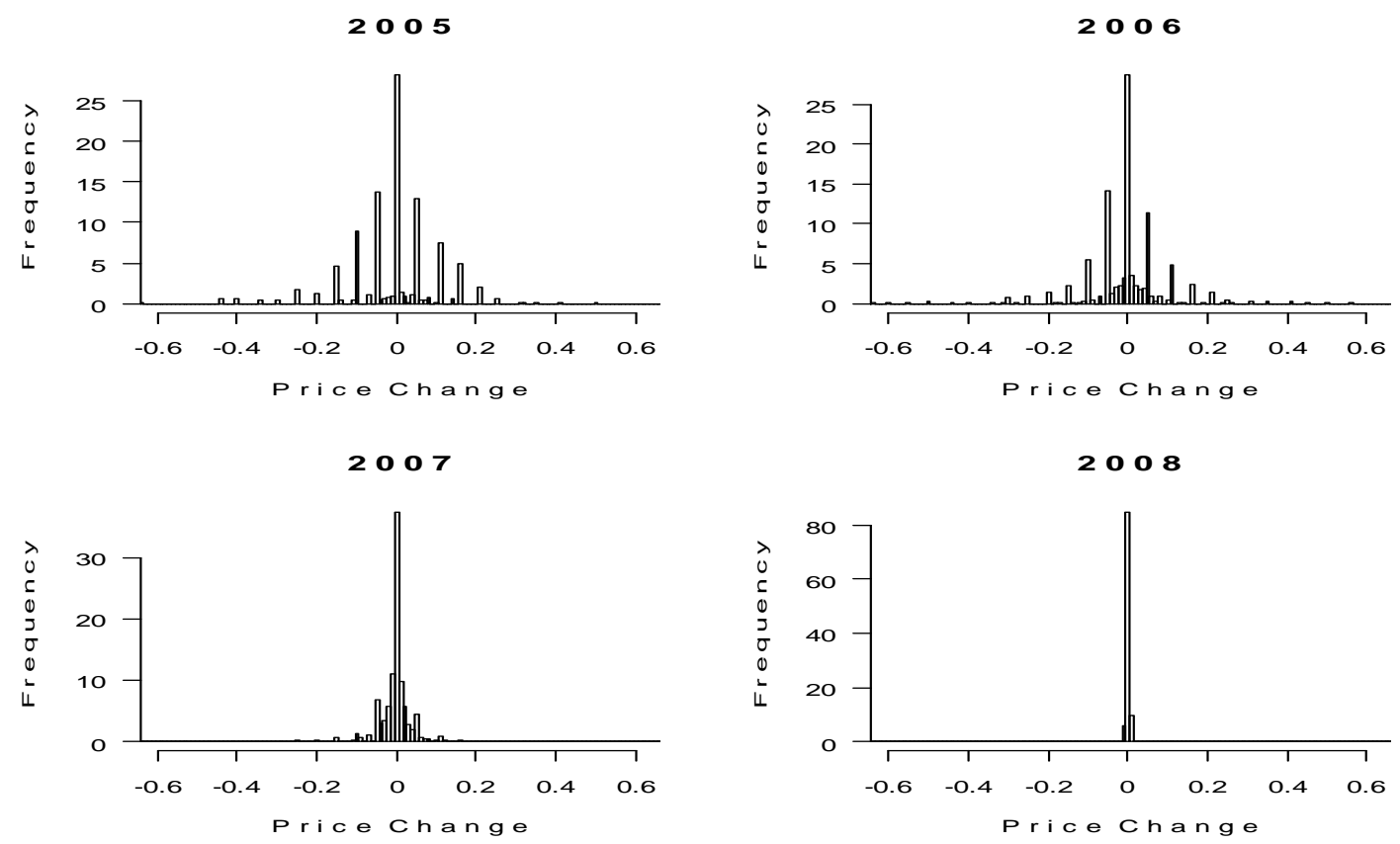

Source: BlueNext. Own calculations.

Figure 2: Empirical distribution of price changes in the EUA futures market (ICE Futures)
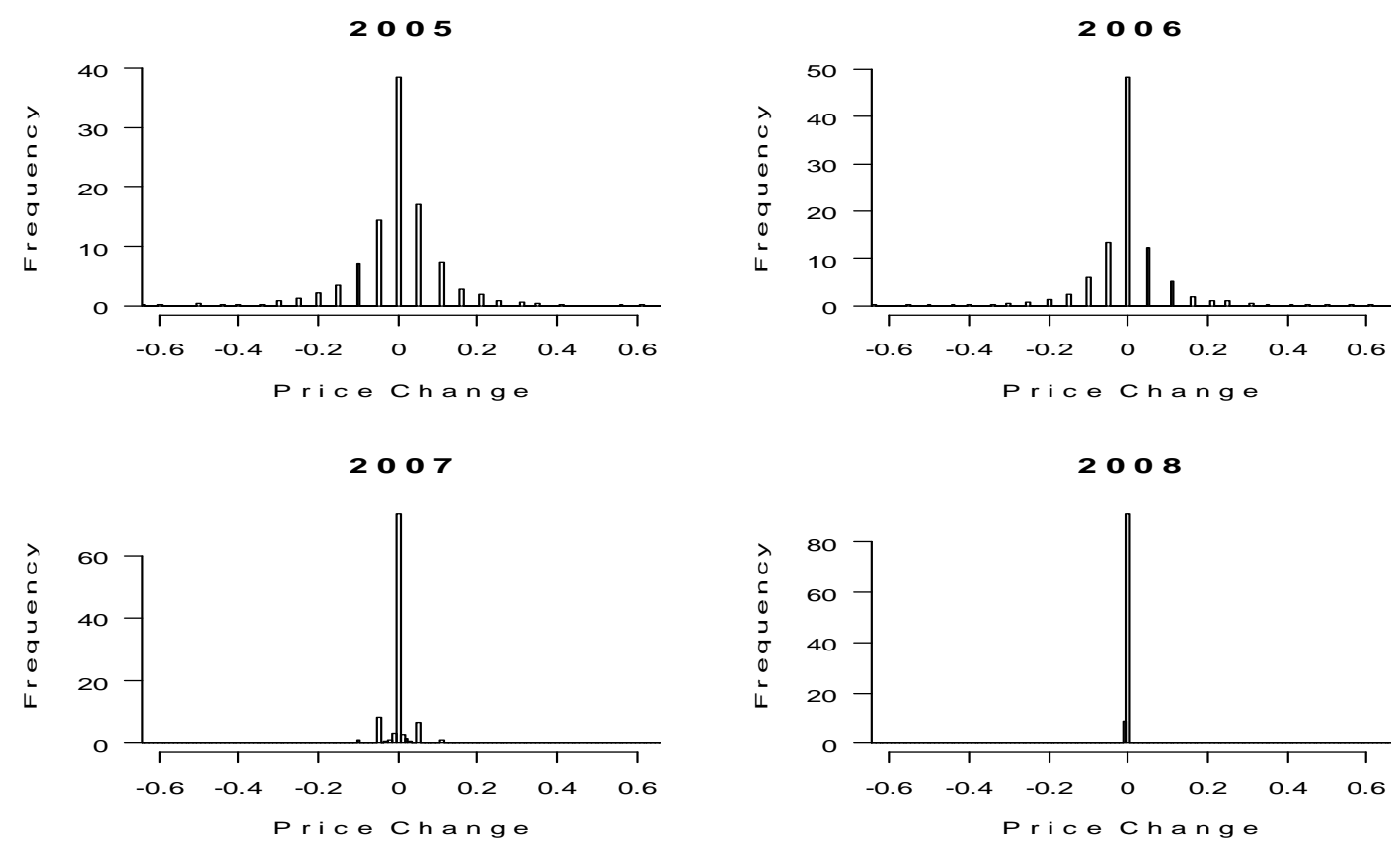

Source: ICE Futures. 2005, 2006, and 2007; price changes in the appropriate December 2005, 2006, or 2007 futures contract, 2008: price changes in the March 2008 futures contract. Own calculations. 
Figure 3: Empirical distribution of price changes in the EUA futures market (ICE Futures)
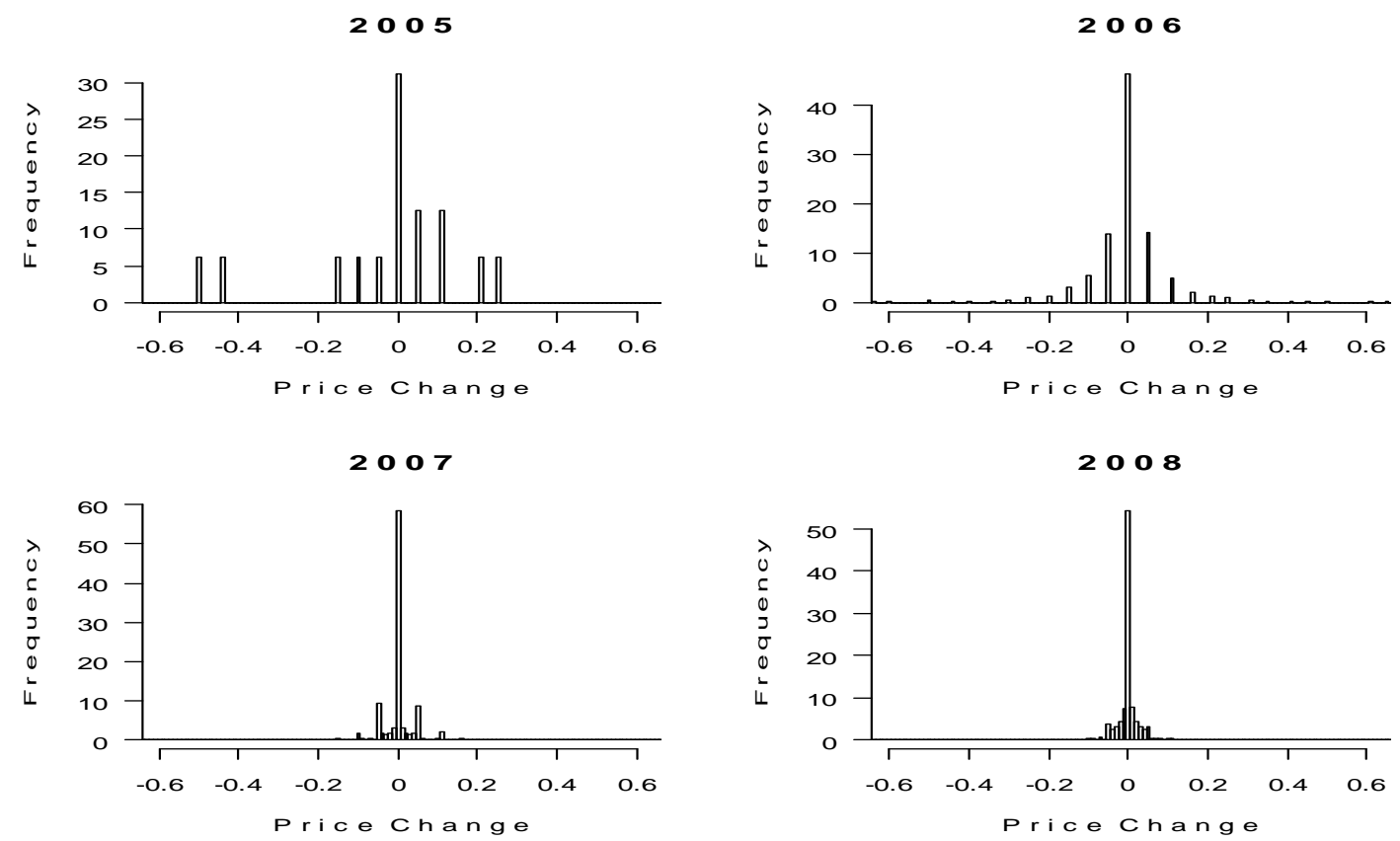

Source: ICE Futures. 2005, 2006, 2007, and 2008; price changes in the December 2008 futures contract of the appropriate year. Own calculations.

Figure 4: Intraday volatility of four EUA markets

Spot market (Phase I)

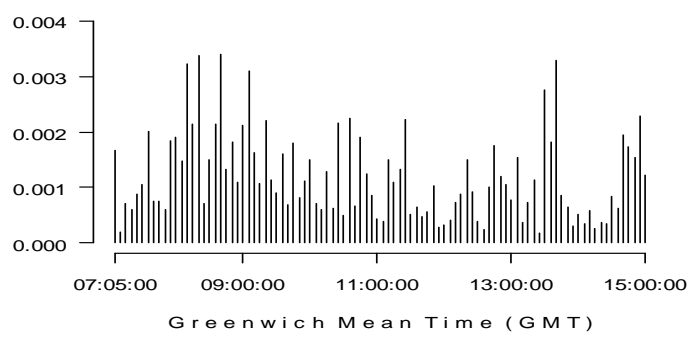

Futures market (Phase I)

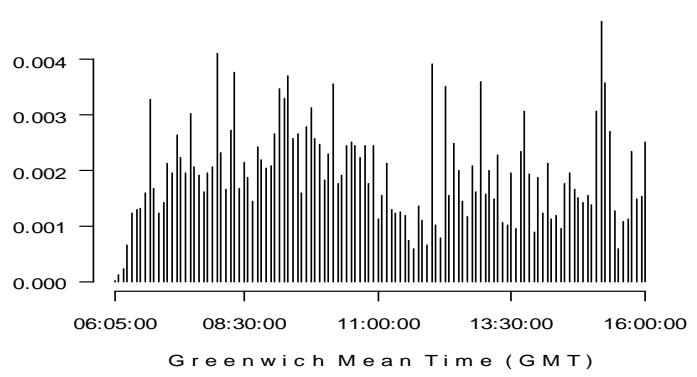

Spot market (Phase II)

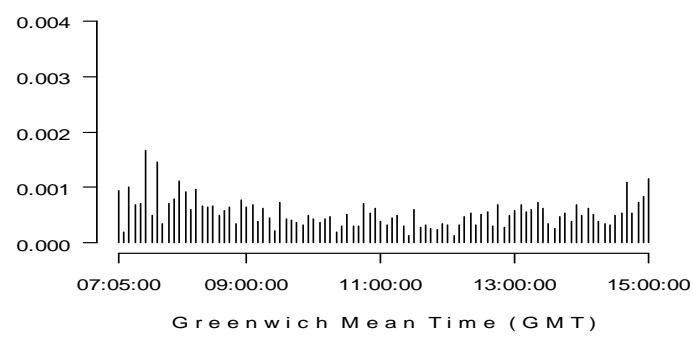

Futures market (Phase II)

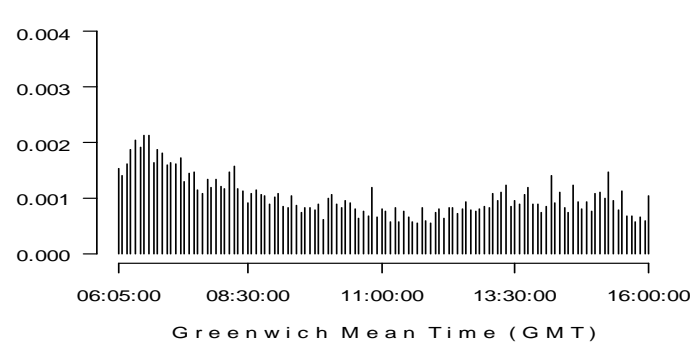

Top left figure: EUA spot market in the first commitment period. Top right figure: EUA spot market in the second commitment period. Bottom left figure: EUA futures market in the first commitment period. Bottom right figure: EUA futures market in the second commitment period. The calculation of the intraday volatility path in the bottom right figure is based on observations until 2008. 
Figure 5: EUA volatility according to four volatility estimates
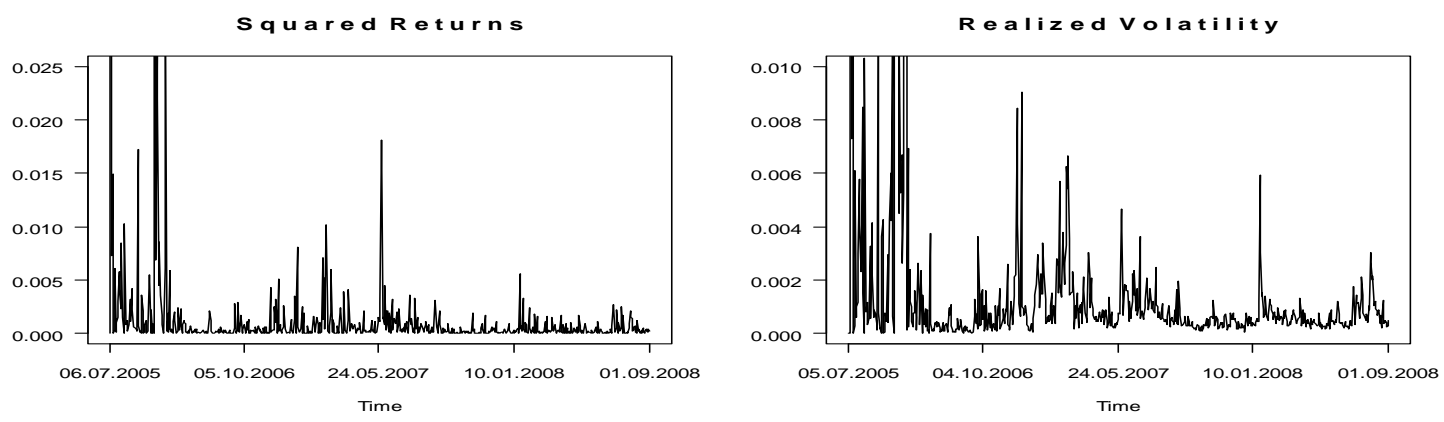

Absolute Returns

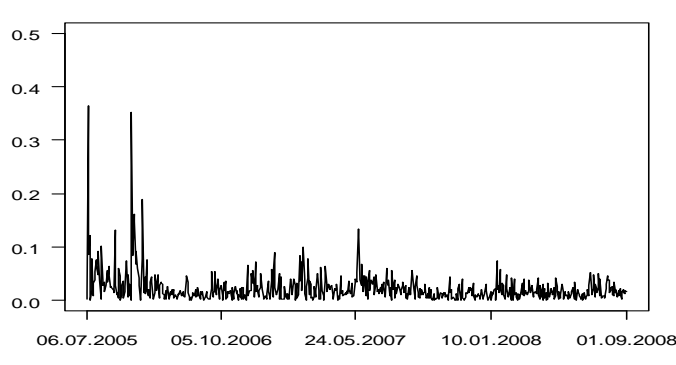

Time

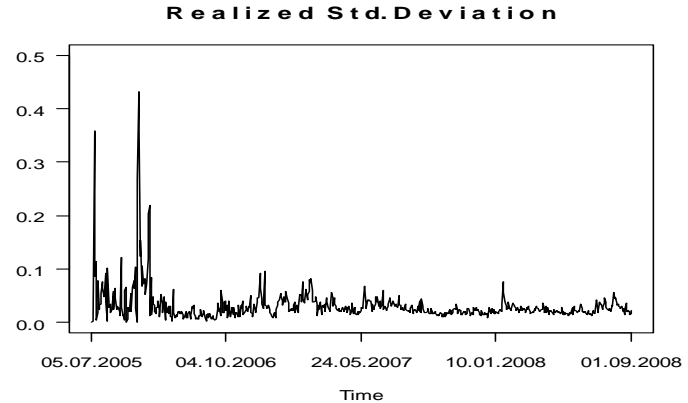

Source: ICE Futures. Own calculations.

Figure 6: Autocorrelation function of considered volatility estimates
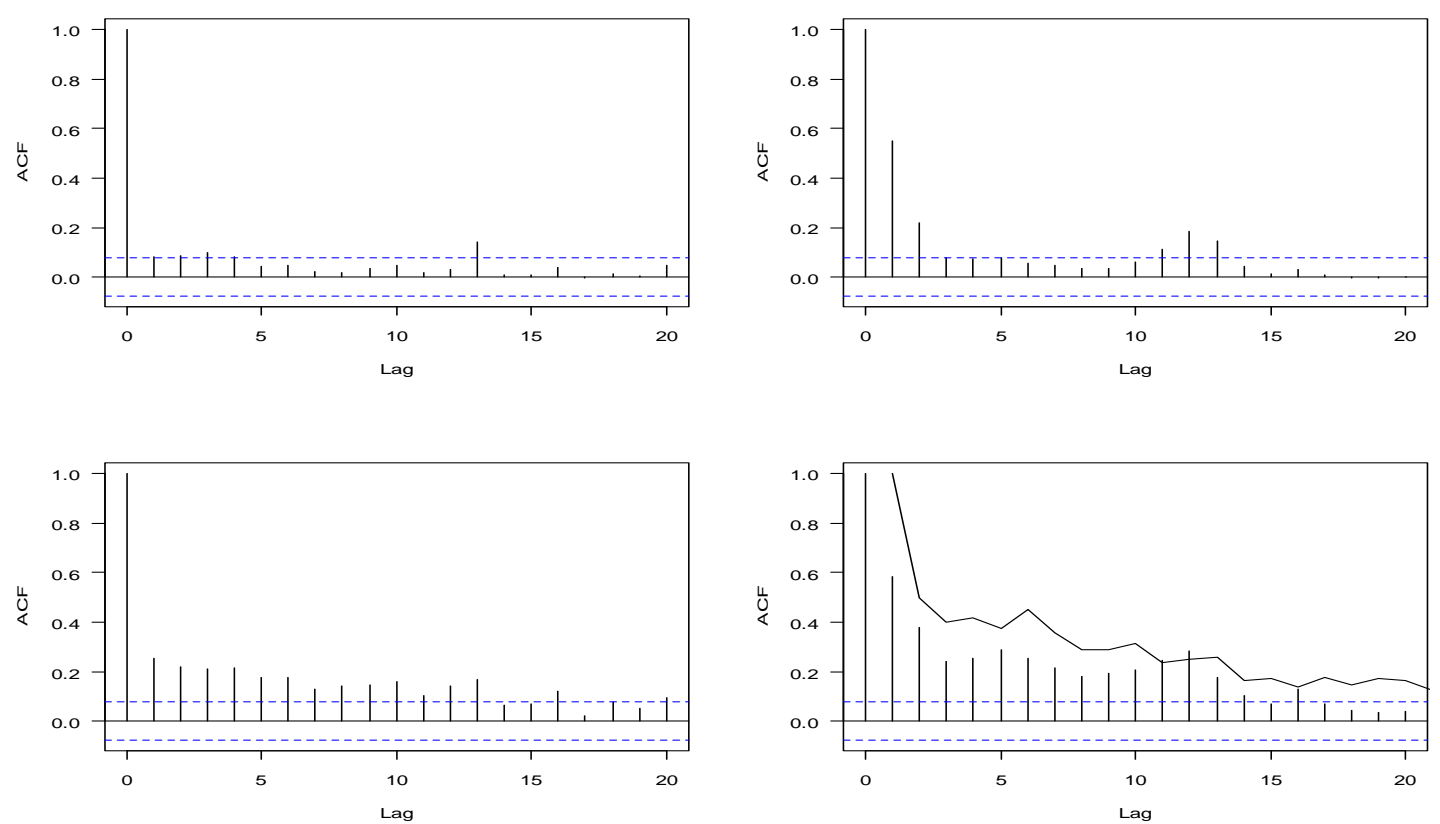

The dashed lines represent Bartlett's confidence limits at a confidence level of 95 percent. Calculations are based on the volatility estimates presented in the previous section. Top left figure: ACF of daily squared returns. Top right figure: ACF of daily realized volatility. Bottom left figure: ACF of daily absolute returns. Bottom right figure: ACF of realized standard deviation (bars) and ACF of logarithmic realized standard deviation (solid line). 
Figure 7: Empirical distribution of price changes in the EUA spot market (BlueNext) in the second commitment period

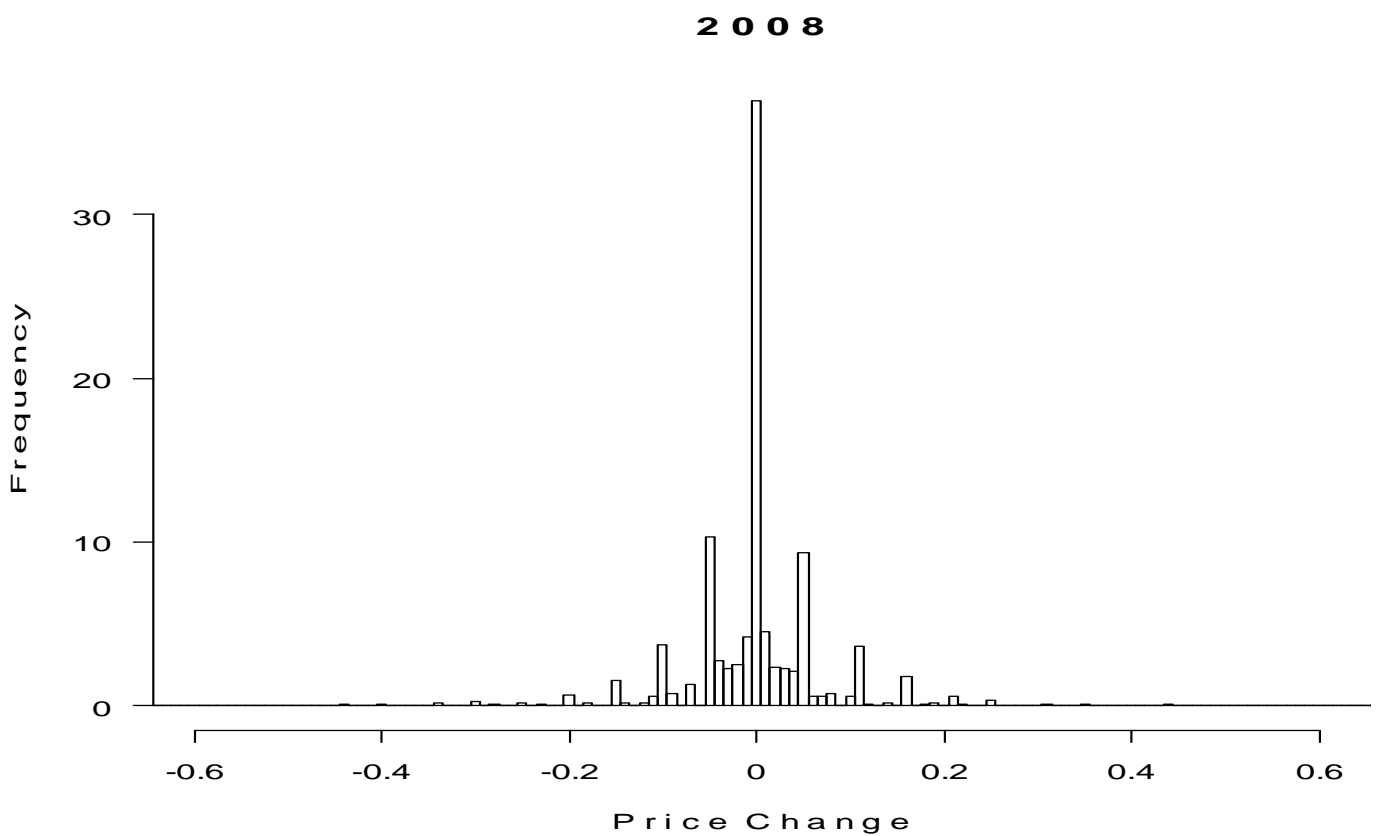

The distribution is based on all on-exchange transactions that occurred until 01/09/2008.

Figure 8: Intraday volatility in the EUA futures market in 2008

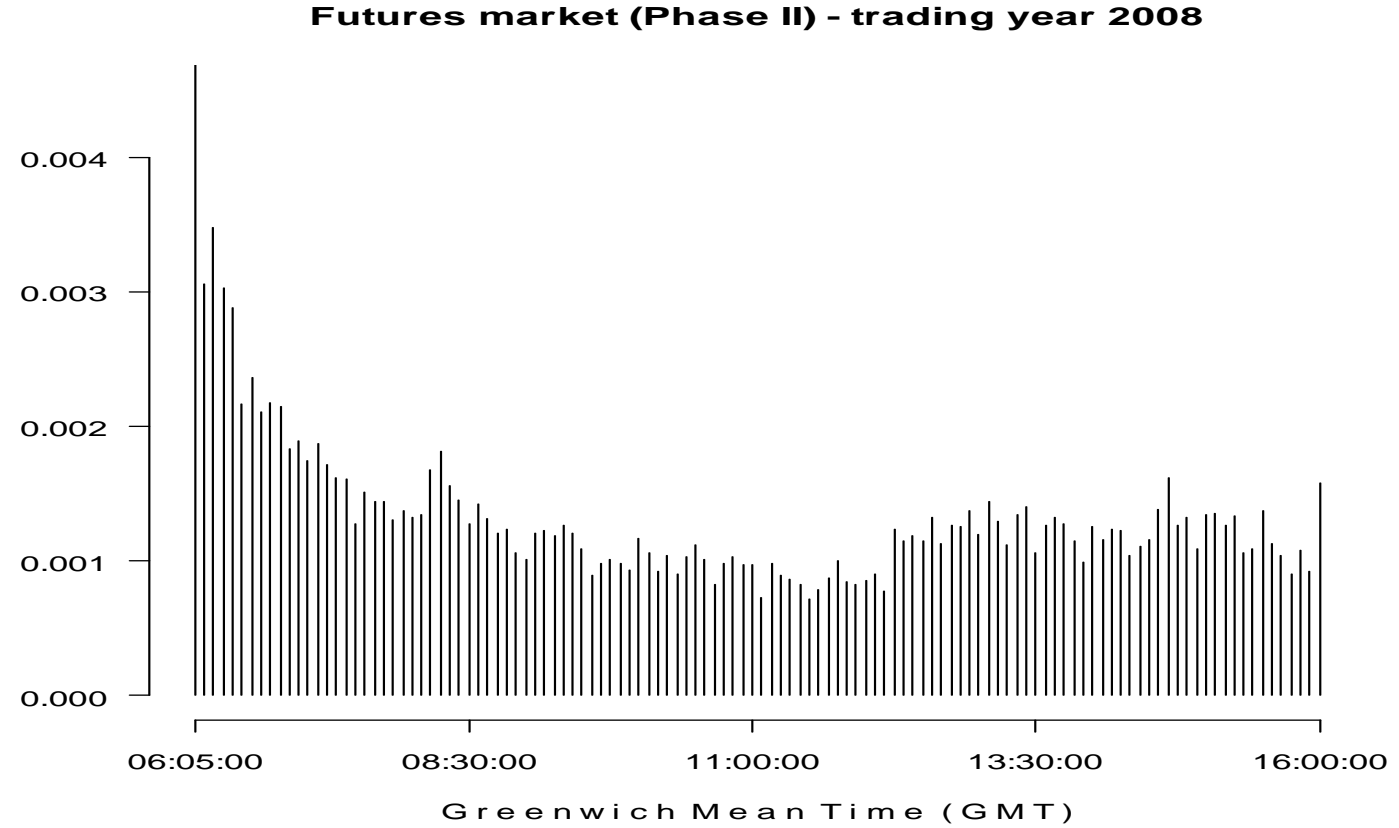

The calculation is based on the December 2008 futures contract transactions in the period from 02/01/2008 until 01/09/2008. 